\title{
Four cardiorespiratory symptoms as predictors of mortality
}

\author{
G. F. TODD AND B. M. HUNT \\ From the Department of Medical Statistics and Epidemiology, London School of Hygiene and Tropical Medicine
}

P. M. LAMBERT

From the Office of Population Censuses and Surveys, London

SUMMARY The power of four cardiorespiratory symptoms to predict subsequent mortality has been analysed in data derived from a random sample of the population of Great Britain recruited in 1965 and followed for 12.4 years. The associations of respiratory symptoms with all causes of death (except stroke) and of cardiovascular symptoms with death from coronary heart disease were strong. The trends of these two associations over the 12.4 years of the follow-up differed substantially: the relative death rates associated with respiratory symptoms remained throughout at about the same level, while those associated with cardiovascular symptoms declined after four years. The excess premature deaths associated with presence of one or more symptoms at entry represented about a quarter of the observed deaths of men and one tenth of those of women.

In 1965, the late Professor D. D. Reid organised the first nationally representative survey in Great Britain of cardiorespiratory symptoms and other personal characteristics, using self-completion postal questionnaires. This sample was part of the United States of America-United Kingdom-Norway collaborative study on migrants (Reid, 1966). Professor Reid was particularly interested in the possibility of using these symptoms as an indicator of increased risk of death from cardiorespiratory disease. Since his death, results have become available from a long-term mortality follow-up of this study and these make it possible to judge how far his hopes for this branch of preventive medicine are likely to be fulfilled. Some results from a three-year follow-up have previously been summarised (Lambert, 1970).

\section{Method}

In the spring of 1965, Professor Reid arranged for AGB Research Ltd. to post questionnaires to members aged 30 or over of a sample of households in Great Britain selected by a randomised procedure (Lambert and Reid, 1970). The sampling fraction in Scotland was increased to four times that in England and Wales, so that the sample should approximately match the constitution of the sample of British migrants to the USA. No corrections for this sampling procedure have been applied in the present analysis.
The original sample comprised 18379 men and women but questionnaires were delivered successfully only to 16884 subjects. Completed replies were received from $12339(73 \%)$. The present paper is based on questionnaires completed by the 10063 subjects aged 35-69, including 88 contacted by field visits and not analysed in the earlier report (Lambert and Reid, 1970). Recruitment lasted from May 1965 until June 1966, the first 9000 aged 35-69 having been recruited during the first month.

The National Health Service Central Register has forwarded a copy of the death certificate of each subject who has since died. The mortality follow-up started on 1 May 1965, and this report is based on deaths in the 12.4-year period before 1 October 1977.

The questions on respiratory symptoms were based on the Medical Research Council questionnaire (1966). Those on cardiovascular symptoms were based on the London School of Hygiene questionnaire (Rose and Blackburn, 1968) and on the questionnaire for self-administration (Rose et al., 1977). This paper is concerned with the prevalence of four symptom categories as adopted by Reid et al. (1966): persistent cough and phlegm, chronic bronchitis, angina, and possible infarction.

The causes of death were analysed in five categories based on the underlying cause of death, coded by the International Classification of Diseases 
(World Health Organisation, 1957): lung cancer (162.1 and 163); coronary heart disease (420 and 422); chronic non-specific lung disease (CNSLD: $502,526$, and 527.1); stroke (330 to 334$)$; and other causes. Further analyses based on any mention of a cause as underlying or contributory yielded similar results and are not given here.

Occasional smokers were classified with 'never' smokers. Except where otherwise stated, 'cigarette smokers' include smokers of hand-rolled cigarettes.

The main results concern the associations between factors (such as symptoms) and various causes of death, after standardising for the confounding variables of age and smoking habits. The follow-up period was split into small time intervals and, within each interval, the observed number of deaths occurring at each age/smoking habit group were compared with the number expected, assuming that the factor had no association with the cause of death concerned. Total observed and total expected numbers were then calculated over all intervals and age/smoking habit groups, and the significance of their deviation was tested by a $\chi^{2}$ statistic as described by Peto and Pike (1973) using the method of Cox (1972). The results are expressed by presenting for each level of the factor the ratio of the total observed to the total expected multiplied by 100 . This form of the relative death rate is analogous to the standardised mortality ratio.

Standardisation for age was based on four categories: age groups 35-44, 45-54, 55-64, and 65-69 years. Standardisation for smoking group was based on three broad categories: 'never' smoker, current cigarette smokers (with or without other products), and others (comprising smokers of other products only, ex-smokers, and those whose cigarette smoking habits were not known). Standardisation for smoking level was based on four categories: $<10,10-19,20$, and $20+$ cigarettes a day.

\section{Results}

\section{REPRESENTATIVENESS}

Table 1 compares the sex, age, urban/rural residence, and social class distributions of the sample with those given by the Registrar General for 1965. The sample contained $47.4 \%$ of men compared with $48.1 \%$ nationally. The differences in age and urban/rural residence were small. The differences in social class, with an excess of Social Class III and a deficiency of Social Class II, were larger, but may have been due in part to differences in definition (Lambert and Reid, 1970). It is doubtful if they could seriously have affected the conclusions.

\section{SMOKING HABITS}

The distribution by smoking habits is compared in
Table 2 with the 1965 Tobacco Research Council national estimates obtained by personal interviews using a quota sample. Taking into account differences in the age range of the samples, and some additional information available in respect of the 'not known' group, the distributions are broadly similar.

Table 1 Distribution of the 10063 subjects by age, urban/rural residence, and social class compared with estimates for Great Britain.

\begin{tabular}{|c|c|c|}
\hline & Sample (\%) & Great Britain (\%) \\
\hline 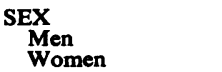 & $\begin{array}{l}47 \cdot 4 \\
52 \cdot 6\end{array}$ & $\begin{array}{l}48 \cdot 1 \\
51 \cdot 9\end{array}$ \\
\hline $\begin{array}{l}\text { AGE GROUP (YEA } \\
35-44 \\
45-54 \\
55-64 \\
65-69\end{array}$ & $\begin{array}{r}30.1 \\
30.6 \\
29.5 \\
9.8\end{array}$ & $\begin{array}{l}31 \cdot 2 \\
30 \cdot 1 \\
28 \cdot 3 \\
10 \cdot 4\end{array}$ \\
\hline $\begin{array}{l}\text { URBAN/RURAL R } \\
\text { Conurbations } \\
\text { Urban }>100000 \\
\text { Urban } 50-100000 \\
\text { Urban }<50000 \\
\text { Rural }\end{array}$ & $\begin{array}{r}35 \cdot 3 \\
14 \cdot 7 \\
8 \cdot 9 \\
23 \cdot 5 \\
17 \cdot 6\end{array}$ & $\begin{array}{l}35 \cdot 7 \\
12 \cdot 7 \\
9 \cdot 5 \\
21 \cdot 7 \\
20 \cdot 4\end{array}$ \\
\hline $\begin{array}{l}\text { SOCIAL CLASS† } \\
\text { II } \\
\text { III } \\
\text { IV } \\
\text { V }\end{array}$ & $\begin{array}{r}2 \cdot 8 \\
11 \cdot 8 \\
57 \cdot 3 \\
21 \cdot 2 \\
7 \cdot 0\end{array}$ & $\begin{array}{r}3 \cdot 3 \\
18 \cdot 5 \\
48 \cdot 0 \\
21 \cdot 6 \\
8 \cdot 6\end{array}$ \\
\hline
\end{tabular}

Table 2 Distribution of smoking habits in study sample aged 35-69 and Tobacco Research Council (TRC) United Kingdom sample aged 35-59†

\begin{tabular}{|c|c|c|c|c|c|c|}
\hline & $\begin{array}{l}\text { Men } \\
\text { Study } \\
\text { No. }\end{array}$ & sample & $\begin{array}{l}\text { TRC } \\
\% \\
\end{array}$ & $\begin{array}{l}\text { Wom } \\
\text { Study } \\
\text { No. } \\
\end{array}$ & sample & $\begin{array}{l}\text { TRC } \\
\% \\
\end{array}$ \\
\hline $\begin{array}{l}\text { Never smokers } \\
\text { Current cigarette smokers } \\
\text { Other current smokers } \\
\text { Ex-smokers } \\
\text { Not known } \\
\text { Total }\end{array}$ & $\begin{array}{r}520 \\
2695 \\
345 \\
905 \\
305 \\
4770\end{array}$ & $\begin{array}{r}10 \cdot 9 \\
56 \cdot 5 \\
7 \cdot 2 \\
19 \cdot 0 \\
6 \cdot 4 \\
100 \cdot 0\end{array}$ & $\begin{array}{r}13 \\
63 \\
7 \\
17 \\
100\end{array}$ & $\begin{array}{r}2120 \\
1893 \\
3 \\
323 \\
954 \\
5293\end{array}$ & $\begin{array}{r}40 \cdot 1 \\
35 \cdot 8 \\
0 \cdot 1 \\
6 \cdot 1 \\
18 \cdot 0 \\
100 \cdot 0\end{array}$ & $\begin{array}{r}40 \\
51 \\
0 \\
9 \\
\overline{100}\end{array}$ \\
\hline
\end{tabular}

†Estimated from Table 11, Lee (1976).

\section{MORTALITY}

After the first five years of follow-up, $6.8 \%$ of the men and $3.8 \%$ of the women had died. By the end of the follow-up, after 12.4 years, $21.8 \%$ of the men and $13.3 \%$ of the women had died. Table 3 shows that death rates for the first two years, especially in women, were unusually low, suggesting, as was to be expected from the experience of other studies (for example, Doll and Peto, 1976), that nonparticipants contained an excessive proportion of those likely to die soon after selection of the sample. 
Table 3 Estimated death rates from all causes by length of follow-up

\begin{tabular}{lccccccl}
\hline & \multicolumn{6}{c}{ Deaths/100 000/year in period } \\
& $1-2$ & $3-4$ & $5-6$ & $7-8$ & $9-10$ & $11-12 \cdot 4$ yrs. \\
\hline Men & 1170 & 1547 & 1551 & 2171 & 2343 & 2779 \\
Women & 473 & 939 & 888 & 1034 & 1629 & 1749 \\
\hline
\end{tabular}

The numbers of deaths by age and cause over the 12.4 years of the study are given in Table 4 . The sexes differed markedly in the distribution of causes: $54.3 \%$ of male deaths, but only $29.7 \%$ of female deaths, were due to the three causes: lung cancer, coronary heart disease, and chronic nonspecific lung disease. The numbers of lung cancer and CNSLD deaths of women were too small for detailed analysis.

The association of smoking with coronary heart disease (CHD) and lung cancer mortality, found in numerous other studies, was confirmed (Table 5). An association with CNSLD in men was also noted, although it was significant only at the $90 \%$ level. No clear associations were noted for stroke or 'other causes' in either sex or for CNSLD in women (where there were only eight deaths).

Table 6 gives, for those causes of death showing a significant association with smoking and with sufficient numbers of deaths for more detailed analysis, the relative mortalities of those currently smoking cigarettes only. Where the numbers of deaths were adequate, the trends in mortality rates by number of cigarettes smoked, age of starting to smoke, and inhalation were similar to those observed by other workers (for example, Hammond, 1966; Doll and Peto, 1976). For example, rates were smallest in those smoking less than 10 cigarettes a day, in those starting to smoke after the age of 20 , and in those who did not inhale, with the single exception that lung cancer rates in males who inhaled were somewhat lower than average, an apparent anomaly that has been noted previously (ibid). None of these trends, with the exception of the clear relationship of male lung cancer rates with number of cigarettes smoked, was statistically significant at the $95 \%$ confidence level, perhaps reflecting the relatively weak trends and small numbers of deaths in some of the groups.

Table 4 Numbers of deaths by age at entry to the study and cause of death

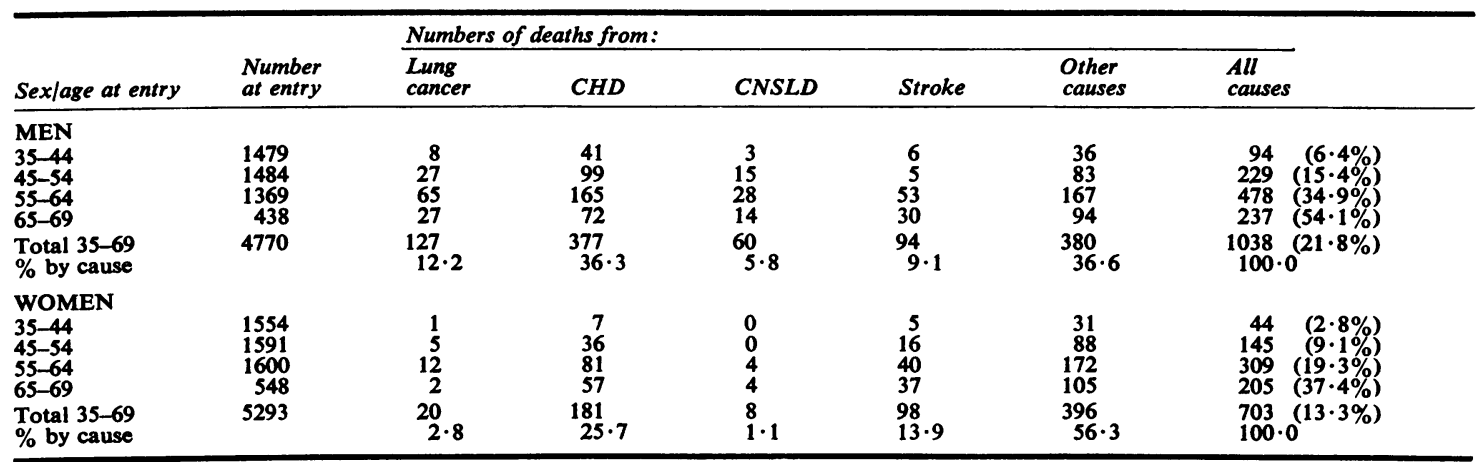

Table 5 Relative mortality ( $x$ 100) $\dagger$ by broad smoking group standardised for age

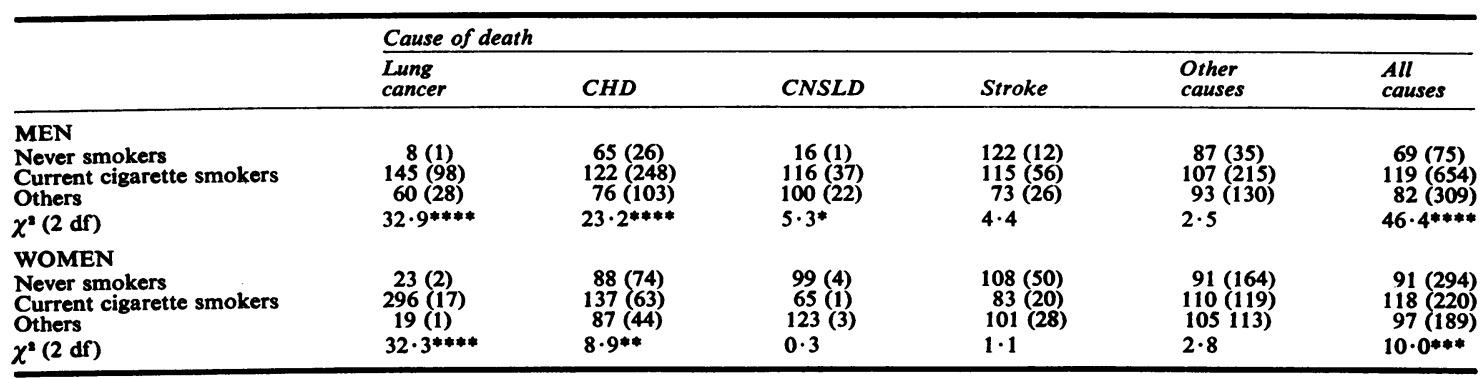

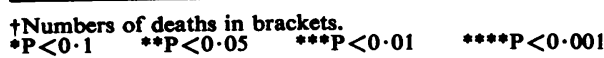


Table 6 Relative mortality $(x$ 100) $\dagger$ in current cigarette only smokers by number of cigarettes smoked (standardised for age), and by age of starting to smoke, inhalation, and type of cigarette smoked (standardised for age and number of cigarettes smoked)

\begin{tabular}{|c|c|c|c|c|c|}
\hline & $\begin{array}{l}\text { Lung } \\
\text { cancer }\end{array}$ & $\begin{array}{l}\text { Men } \\
C H D\end{array}$ & $\begin{array}{l}\text { All } \\
\text { causes }\end{array}$ & $\begin{array}{l}\text { Women } \\
\text { CHD }\end{array}$ & $\begin{array}{l}\text { All } \\
\text { causes }\end{array}$ \\
\hline $\begin{array}{l}\text { NO. OF CIGARETTES SMOKED } \\
<10 \\
10-19 \\
20 \\
20+ \\
\chi^{2}(3 \text { df })\end{array}$ & $\begin{array}{l}50(7) \\
85(32) \\
132(23) \\
162(19) \\
11 \cdot 0^{* *}\end{array}$ & $\begin{array}{l}77(25) \\
112(105) \\
91(40) \\
101(31) \\
3 \cdot 5\end{array}$ & $\begin{array}{l}82(71) \\
103(245) \\
107(118) \\
102(77) \\
3 \cdot 8\end{array}$ & $\begin{array}{l}89(14) \\
99(22) \\
122(10) \\
106(2) \\
0.6\end{array}$ & $\begin{array}{l}88(44) \\
102(75) \\
119(33) \\
93(6) \\
2 \cdot 0\end{array}$ \\
\hline $\begin{array}{l}\text { AGE OF STARTING TO SMOKE } \\
<16 \\
16-19 \\
20+\end{array}$ & $\begin{array}{r}118(29) \\
96(39) \\
82(12)\end{array}$ & $\begin{array}{l}100(57) \\
108(109) \\
80(30)\end{array}$ & $\begin{array}{c}101(150) \\
104(273) \\
87(84)\end{array}$ & $\begin{array}{r}117(4) \\
98(13) \\
99(30)\end{array}$ & $\begin{array}{l}123(14) \\
116(53) \\
90(89)\end{array}$ \\
\hline$\chi^{3}(2 \mathrm{df})$ & $1 \cdot 4$ & $2 \cdot 2$ & $2 \cdot 1$ & $0 \cdot 1$ & $3 \cdot 2$ \\
\hline $\begin{array}{l}\text { Yes } \\
\text { No } \\
\chi^{2}(1 \text { df) } \\
\text { TYPE OF CIGARETTE }\end{array}$ & $\begin{array}{l}93(61) \\
133(18) \\
2 \cdot 0\end{array}$ & $\begin{array}{l}106(172) \\
72(24) \\
3 \cdot 4^{*}\end{array}$ & $\begin{array}{l}103(425) \\
87(78) \\
2 \cdot 0\end{array}$ & $\begin{array}{l}105(28) \\
94(20) \\
0 \cdot 2\end{array}$ & $\begin{array}{l}105(92) \\
94(62) \\
0.6\end{array}$ \\
\hline $\begin{array}{l}\text { Filter only } \\
\text { Plain only } \\
\chi^{2}(1 \text { df })\end{array}$ & $\begin{array}{l}118(32) \\
84(26) \\
1 \cdot 7\end{array}$ & $\begin{array}{r}85(64) \\
114(90) \\
3 \cdot 5 *\end{array}$ & $\begin{array}{l}91(166) \\
108(212) \\
3 \cdot 4^{*}\end{array}$ & $\begin{array}{l}101(30) \\
98(12) \\
0.0\end{array}$ & $\begin{array}{r}90(91) \\
124(50) \\
3 \cdot 5^{*}\end{array}$ \\
\hline
\end{tabular}

+ Numbers of deaths in brackets.

$* \mathrm{P}<0.1 \quad * \mathrm{P}<0.05 \quad * * \mathrm{P}<0.01 \quad * * * \mathrm{P}<0.001$

The difference between smokers of filter and plain cigarettes in total death rates is of special interest (although no doubt many of the plain smokers studied are likely to have switched to filter cigarettes during the follow-up period, so that to some extent the comparison is between people switching before 1965 and those switching afterwards). When the male and female mortality figures are combined, the total death rate for filter smokers is $18 \%$ less than that for plain smokers. $\left(\chi^{2}=5.6\right.$ on $\left.1 \mathrm{df}, \mathrm{P}<0.05\right)$. The magnitude of this difference is similar to that found by Hammond et al. (1976) in a comparison between smokers of high and low tar/nicotine cigarettes (to a considerable extent this would also have been a comparison of plain and filter cigarettes). Somewhat surprising, however, is the (non-significant) reverse trend observed for lung cancer mortality in males, as both Hammond (1966) and more recently Dean et al. (1977), have noted a substantial reduction in lung cancer death rates in smokers of lower tar/ nicotine and filter cigarettes.

\section{MORTALITY BY PREVALENCE OF SYMPTOMS AT ENTRY}

Table 7 shows, for each cause of death, the proportion in which symptoms were present at entry to the study. There were few deaths from CNSLD, especially in women, but a high proportion had had respiratory symptoms. Apart from these, no individual symptom was associated with more than $40 \%$ of the deaths from any of the five causes of death. Among men dying of CHD, only about a quarter had angina at entry, and about a quarter had possible infarction.

Table 7 Percentage of deaths $\dagger$ from each cause in which specified symptoms were present at entry to the study

\begin{tabular}{|c|c|c|c|c|c|c|}
\hline \multirow[b]{2}{*}{ Sex/symptom at entry } & \multicolumn{6}{|c|}{ Cause of death } \\
\hline & $\begin{array}{l}\text { Lung } \\
\text { cancer }\end{array}$ & CHD & CNSLD & Stroke & $\begin{array}{l}\text { Other } \\
\text { causes }\end{array}$ & $\begin{array}{l}\text { All } \\
\text { causes }\end{array}$ \\
\hline \multirow{2}{*}{$\begin{array}{l}\text { MEN } \\
\text { Persistent cough and phlegm } \\
\text { Chronic bronchitis } \\
\text { Angina } \\
\text { Possible infarction } \\
\text { At least one of the four } \\
\text { symptoms } \\
\text { Total deaths }\end{array}$} & $\begin{array}{l}35 \cdot 4(45) \\
11 \cdot 0(14) \\
11 \cdot 0(14) \\
18 \cdot 9(24)\end{array}$ & $\begin{array}{l}26 \cdot 8(101) \\
13 \cdot 5(51) \\
27 \cdot 3(103) \\
26 \cdot 0(98)\end{array}$ & $\begin{array}{l}76 \cdot 7(46) \\
63 \cdot 3(38) \\
33 \cdot 3(20) \\
38 \cdot 3(23)\end{array}$ & $\begin{array}{r}20 \cdot 2(19) \\
7.4(7) \\
20 \cdot 2(19) \\
17.0(16)\end{array}$ & $\begin{array}{l}25 \cdot 8(98) \\
11 \cdot 8(45) \\
18 \cdot 2(69) \\
14 \cdot 5(55)\end{array}$ & $\begin{array}{l}29.8(309) \\
14.9(155) \\
21.7(225) \\
20.8(216)\end{array}$ \\
\hline & $\begin{array}{l}46 \cdot 5(59) \\
127\end{array}$ & $\begin{array}{l}50 \cdot 7(191) \\
377\end{array}$ & $\begin{array}{l}86 \cdot 7(52) \\
60\end{array}$ & $\begin{array}{l}40 \cdot 4(38) \\
94\end{array}$ & $\begin{array}{l}41 \cdot 6(158) \\
380\end{array}$ & $\begin{array}{l}48 \cdot 0(498) \\
1038\end{array}$ \\
\hline \multirow{2}{*}{$\begin{array}{l}\text { WOMEN } \\
\text { Persistent cough and phlegm } \\
\text { Chronic bronchitis } \\
\text { Angina } \\
\text { Possible infarction } \\
\text { At least one of the four } \\
\text { symptoms } \\
\text { Total deaths }\end{array}$} & $\begin{array}{l}40.0(8) \\
25.0(5) \\
15.0(3) \\
20.0(4)\end{array}$ & $\begin{array}{r}13 \cdot 3(24) \\
7 \cdot 2(13) \\
19 \cdot 9(36) \\
17 \cdot 7(32)\end{array}$ & $\begin{array}{l}62 \cdot 5(5) \\
50 \cdot 0(4) \\
25 \cdot 0(2) \\
25 \cdot 0(2)\end{array}$ & $\begin{array}{c}5 \cdot 1(5) \\
1 \cdot 0(1) \\
18 \cdot 4(18) \\
12 \cdot 2(12)\end{array}$ & $\begin{array}{r}8 \cdot 1(32) \\
4 \cdot 5(18) \\
11 \cdot 9(47) \\
8 \cdot 8(35)\end{array}$ & $\begin{array}{r}10 \cdot 5(74) \\
5 \cdot 8(41) \\
15 \cdot 1(106) \\
12 \cdot 1(85)\end{array}$ \\
\hline & $\begin{array}{l}45 \cdot 0(9) \\
20\end{array}$ & $\begin{array}{l}38 \cdot 1(69) \\
181\end{array}$ & $\begin{array}{l}75 \cdot 0(6) \\
8\end{array}$ & $\begin{array}{l}24 \cdot 5(24) \\
98\end{array}$ & $\begin{array}{l}21 \cdot 5(85) \\
396\end{array}$ & $\begin{array}{l}27 \cdot 5(193) \\
703\end{array}$ \\
\hline
\end{tabular}

†Numbers of deaths in brackets. 
Table 8 Relative mortality $(x$ 100) for those with specified symptoms at entry compared with those without (standardised for age and smoking)

\begin{tabular}{|c|c|c|c|c|c|c|}
\hline & $\begin{array}{l}\text { Lung } \\
\text { cancer }\end{array}$ & $C H D$ & CNSLD & Stroke & $\begin{array}{l}\text { Other } \\
\text { causes }\end{array}$ & $\begin{array}{l}\text { All } \\
\text { causes }\end{array}$ \\
\hline $\begin{array}{l}\text { MEN } \\
\text { Persistent cough and phlegm } \\
\text { Chronic bronchitis } \\
\text { Angina } \\
\text { Possible infarction } \\
\text { At least one of the four symptoms }\end{array}$ & $\begin{array}{l}160 * * * \\
134 \\
83 \\
163 * * \\
150^{* *}\end{array}$ & $\begin{array}{l}127 * * \\
201 * * * * \\
275 * * * * \\
256 * * * * \\
204 * * * *\end{array}$ & $\begin{array}{r}1126 * * * * \\
2059 * * * * \\
347 * * * * \\
445 * * * * \\
1257 * * * *\end{array}$ & $\begin{array}{c}86 \\
86 \\
163^{*} \\
151 \\
130\end{array}$ & $\begin{array}{l}131 * * * \\
171 * * * * \\
157 * * * * \\
125 \\
146 * * * *\end{array}$ & $\begin{array}{l}148^{* * * * *} \\
215^{* * * * *} \\
195 * * * * \\
192 * * * * \\
181^{* * * *}\end{array}$ \\
\hline $\begin{array}{l}\text { WOMEN } \\
\text { Persistent cough and phlegm } \\
\text { Chronic bronchitis } \\
\text { Angina } \\
\text { Possible infarction } \\
\text { At least one of the four symptoms }\end{array}$ & $\begin{array}{l}371 * * * * \\
489 * * * * \\
125 \\
265 * \\
209 *\end{array}$ & $\begin{array}{l}155 * * \\
188 * * \\
180 * * * \\
220 * * * * \\
204 * * * *\end{array}$ & $\begin{array}{l}2191 * * * * \\
3047 * * * * \\
229 \\
320 \\
1027 * * * *\end{array}$ & $\begin{array}{c}66 \\
30 \\
159 * \\
143 \\
115\end{array}$ & $\begin{array}{r}95 \\
120 \\
101 \\
102 \\
95\end{array}$ & $\begin{array}{l}124^{* *} \\
155^{* * *} \\
13^{*} 0^{* *} \\
143^{* * *} \\
129 * * *\end{array}$ \\
\hline
\end{tabular}

*P<0.1 **P<0.05 ***P<0.01 ****P<0.001

To some extent these figures reflect the prevalence of symptoms in the population. It is interesting, therefore, to study also the relative death rates of people with and without symptoms. Table 8 presents these rates, standardised for age and smoking habits in order to answer the question: 'Is someone of given age and smoking habits with symptoms more at risk than someone without?' It can be seen that for any symptom studied, and for either sex, there is a highly significant excess total death rate in people reporting symptoms at entry compared with those who did not report them. Mortality from CNSLD is enormously greater in those with respiratory symptoms. Angina and possible infarction are associated clearly with death from CHD (and possibly with death from stroke). There is also a form of reciprocal relationship, in that respiratory symptoms are highly associated with death from CHD, while chest pain is highly associated with death from CNSLD. It is interesting that more men and women with chronic bronchitis died of CHD than of CNSLD. Lung cancer mortality in men shows a weak association with the prevalence of phlegm production. In women, the positive associations with respiratory symptoms are larger in magnitude, but because of the small total number of deaths (20) the confidence limits are wide. Deaths from other causes in men are significantly but not particularly strongly associated with the presence of respiratory symptoms or angina at entry. Having 'at least one' of the symptoms was associated with generally increased mortality. On the other hand, some specific symptom was always more closely related to each of the associated causes of death than 'at least one' of the symptoms.

CHANGES IN SYMPTOM/MORTALITY

ASSOCIATIONS OVER TIME

Twelve and a half years is a long period in which to seek an effect related to an ascertained symptom. It is therefore appropriate to ask how the association of mortality with symptoms changed during the follow-up period (Table 9). CNSLD has not been included in this Table because there were so few deaths from this cause in persons without symptoms. Lung cancer and stroke are omitted because the symptomatic associations were anyway relatively weak.

Table 9 Relative CHD and total mortality (x 100) for those with specified symptoms at entry compared with those without by period of follow-up (standardised for age and smoking)

\begin{tabular}{|c|c|c|c|c|}
\hline & $\begin{array}{l}\text { CHD } \\
\text { Period of } \\
1-5\end{array}$ & $\begin{array}{l}\text { follow-ut } \\
6-12 \cdot 4\end{array}$ & $\begin{array}{l}\text { All causes } \\
\text { (years) } \\
1 \cdot 5\end{array}$ & $6-12 \cdot 4$ \\
\hline \multirow[t]{2}{*}{$\begin{array}{l}\text { MEN } \\
\text { Persistent cough and phlegm } \\
\text { Chronic bronchitis } \\
\text { Angina } \\
\text { Possible infarction } \\
\text { At least one of the four } \\
\text { symptoms }\end{array}$} & $\begin{array}{l}116 \\
203 * * * \\
477 * * * * \\
478 * * * *\end{array}$ & $\begin{array}{l}133 * * \\
200 * * * * \\
199 * * * * \\
177 * * * *\end{array}$ & $\begin{array}{l}138 * * * \\
223 * * * * \\
256 * * * * \\
269 * * * *\end{array}$ & $\begin{array}{l}153 * * * * \\
211 * * * * \\
167 * * * * \\
158 * * * *\end{array}$ \\
\hline & $298 * * * *$ & $172 * * * *$ & $212 * * * *$ & $169 * * * *$ \\
\hline \multirow[t]{2}{*}{$\begin{array}{l}\text { WOMEN } \\
\text { Persistent cough and phlegm } \\
\text { Chronic bronchitis } \\
\text { Angina } \\
\text { Possible infarction } \\
\text { At least one of the four } \\
\text { symptoms }\end{array}$} & $\begin{array}{l}190 \\
199 \\
262 * * * \\
351 * * * *\end{array}$ & $\begin{array}{l}146 \\
185^{*} \\
160^{* *} \\
189^{* * *}\end{array}$ & $\begin{array}{l}113 \\
130 \\
151 * * \\
137\end{array}$ & $\begin{array}{l}128^{*} \\
165^{* * *} \\
123^{*} \\
146^{* * *}\end{array}$ \\
\hline & $364 * * * *$ & $173 * * *$ & $139 * *$ & $125 * *$ \\
\hline
\end{tabular}

Two conclusions emerge clearly from Table 9. Firstly, the number of significant associations with mortality in the second part of the follow-up period shows that the value of symptoms as predictors of death is not exhausted within the first few years after their ascertainment. Secondly, there are differences in the patterns of the associations between symptoms and mortality in the two periods. For respiratory symptoms, the magnitude of the associations is about as large in the second as in the first period. In contrast, for chest pain, the association with CHD mortality is much stronger in the first period. In fact, among angina-positives, $44 \%$ of CHD deaths occurred in the first period, whereas among angina-negatives only $22 \%$ did. 
Nevertheless, even in the second period, angina and possible infarction still had considerable associations with death from CHD.

These trends are analysed in more detail in Table 10. The lack of standardisation should not materially affect the comparison between time periods. The figures show that the predictive power of chest pain for death from CHD reached a peak at about three to four years after the time of ascertainment. They also show that the relative mortalities for persistent cough and phlegm were remarkably constant over the whole period studied.

Table 10 Relative mortality ( $x$ 100) for certain causes of death for those with specified symptoms at entry compared with those without by two-year period of follow-up (unstandardised)-males

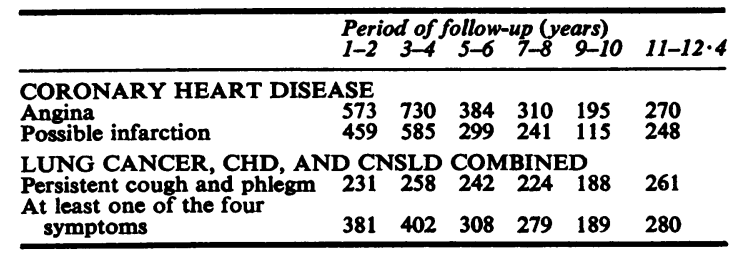

SYMPTOMS AS PREDICTORS OF PREMATURE DEATH

A prime concern of the study was premature death. For the purpose of this paper, a 'premature death' was defined as a death of a person aged 35-54 on entry at any time during the follow-up or a person aged 55-64 at entry during the first five years of the follow-up; any such death would have occurred under the age of 70 . There were 469 premature deaths of men and 279 of women. How many of these deaths represent the excess of the death rates in those with cardiorespiratory symptoms over those (of the same age and smoking habits) without symptoms? In order to avoid multiple counting of excess deaths in subjects with more than one symptom, the analysis in Table 11 is based on subjects with any one or more of the four symptoms. The results show that about one death in four of the men in this group, and about one death in 10 of the women, would be regarded as excess symptom-related premature deaths. It is possible that many of these deaths could have been deferred, perhaps for many years, had the subject been identified sooner.

\section{Conclusions}

Three major conclusions can be drawn from the evidence presented in this paper:

1. An increased risk of death from cardiorespiratory disease which persists for at least 12 years can be shown in men and women identified, without too much difficulty, as having any one of four cardiorespiratory symptoms.

2. The association between chest pain and death from CHD mortality was much stronger in the first four years of follow-up than later. The associations between persistent cough and phlegm or bronchitis and death from cardiorespiratory diseases on the other hand were relatively constant over the whole 12.4-year period.

3. The premature deaths of about one man in four and one woman in 10 can be linked with the associations between symptom and mortality.

It should be emphasised that these associations do not necessarily mean that the symptoms caused the deaths, or even that they were on the direct pathway to death. Some symptoms may well have been, as Dean $e t$ al. (1978) have pointed out, only non-specific short-term effects. In some cases, the symptoms would have been false positives, and some of those not reporting symptoms would have been false negatives. Rose $(1968 ; 1971)$, for example, has described the variability with time of the reporting of angina and possible infarction. Nevertheless, it is concluded here that the associations of certain symptoms and causes of death were sufficiently well established to indicate an increased probability of premature death of those with the symptoms.

\section{Discussion}

After an analysis of the same symptoms in relation to deaths from all causes in Norwegians, Young (1974) stated that "while one cannot conclude . . . that persons reporting symptoms were at an increased risk of dying from those symptoms, one

Table 11 Excess 'premature deaths' from all causes associated with possession of one or more of the four cardiorespiratory symptoms (standardised for age and smoking habits)

\begin{tabular}{|c|c|c|c|c|c|c|}
\hline & $\begin{array}{l}\text { Men } \\
\text { Age group (years) } \\
35-54\end{array}$ & $55-64$ & $35-64$ & $\begin{array}{l}\text { Women } \\
\text { Age group (years) } \\
35-54\end{array}$ & $55-64$ & $35-64$ \\
\hline Relative death rate in symptom positive & $1 \cdot 93$ & $2 \cdot 24$ & & $1 \cdot 41$ & $1 \cdot 72$ & \\
\hline
\end{tabular}


can conclude that the reporting of a symptom does identify a person who is at an increased risk of dying due to some cause within five years from the date of questionnaire'. A similar conclusion was reached in this study, except that the association we found was not limited to five years. On the other hand, we preferred when possible to draw conclusions in respect of specific symptoms, since these were more closely associated with specific causes of death.

Higgins and Keller (1970) concluded from their study of the adult population of Tecumseh that 'shortness of breath was the best single predictor of mortality and especially of mortality from coronary heart disease. The risks associated with cough and phlegm in the absence of shortness of breath are very small'. A question on shortness of breath was included in the present study and a positive answer was one of our criteria for chronic bronchitis. Thus shortness of breath may well have been largely responsible for the association of chronic bronchitis with death from CHD.

Fletcher et al. (1976) stated that 'Krueger et al. (1970) reported increased mortality in people with persistent cough and phlegm, but others have shown that this risk in people with productive cough disappears after allowing for dyspnoea (Higgins and Keller, 1970) or for FEV level (Cole, 1975)'. It was not possible to measure FEV level in the present study, and we have treated phlegm production (which does not include dyspnoea) and chronic bronchitis (which does include it) as separate groups of symptoms.

In their study of the mortality of British civil servants in Whitehall, Rose et al. (1977) concluded that angina and possible infarction both predicted a relatively high proportion of CHD deaths in the next five years. This also is consistent with the conclusions of the present study, but the predictive values of angina and possible infarction were not limited to five years.

Clearly, not all those with a cardiorespiratory symptom will die prematurely. Only for chronic bronchitis did more than half of those affected die within the 12.4 year follow-up period. Nevertheless, the proportion of those with one or more of the symptoms described in this paper who will die prematurely is considerably greater than the proportion of those of the same age and smoking habits who do not have the symptom. The fact that this excess mortality can still be observed long after the symptoms have been ascertained is one of the most important conclusions of the present paper. Consequently, screening surveys designed to identify those with cardiorespiratory symptoms, which the late Donald Reid did so much to improve and encourage, should not be considered as exhausting their benefits for preventive medicine within just a few years.

We thank Mr. P. N. Lee, who planned the computing and made a major contribution to the statistical analysis; also Mrs. Elizabeth Killick, Mrs. Anne Poole, and the Office of Population Censuses and Surveys. The study was assisted by grants from the National Institutes of Health (US Public Health Service grant HE 04775) and from the Tobacco Research Council. Professor D. D. Reid always deeply appreciated the financial support given continuously to the work of his Department since 1962 by the Tobacco Research Council.

Reprints from Mrs. B. M. Hunt, Department of Medical Statistics and Epidemiology, London School of Hygiene and Tropical Medicine, Keppel Street, London WC1E 7HT.

\section{References}

Cole, T. J. (1975). Linear and proportional regression models in the prediction of ventilatory function. Journal of the Royal Statistical Society, Series A, 138, 297-337.

Cox, D. R. (1972). Regression methods and life tables (with discussion). Journal of the Royal Statistical Society, Series B, 34, 187-220.

Dean, G., Lee, P. N., Todd, G. F., and Wicken, A. J. (1977). Report on a Second Retrospective Mortality Study in North-East England. Part I. Factors relating to mortality from lung cancer, bronchitis, heart disease and stroke in Cleveland County, with particular emphasis on the relative risks associated with smoking filter and plain cigarettes. Tobacco Research Council, Research Paper No. 14. Tobacco Research Council: London.

Dean, G., Lee, P. N., Todd, G. F., Wicken, A. J., and Sparks, D. N. (1978). Factors related to respiratory and cardiovascular symptoms in the United Kingdom. Journal of Epidemiology and Community Health, 32, 86-96.

Doll, R., and Peto, R. (1976). Mortality in relation to smoking. 20 years' observations on male British doctors. British Medical Journal, 2, 1525-1536.

Fletcher, C. M., Peto, R., Tinker, C., and Speizer, F. E. (1976). The Natural History of Chronic Bronchitis and Emphysema. Oxford University Press: London.

Hammond, E. C. (1966). Smoking in relation to the death rates of one million men and women. National Cancer Institute. Monograph No. 19, pp. 127-204. National Cancer Institute: Bethesda.

Hammond, E. C., Garfinkel, L., Seidman, H., and Lew, E. A. (1976). 'Tar' and nicotine contents of cigarette smoke in relation to death rates. $E n$ vironmental Research, 12, 263-274.

Higgins, M. W., and Keller, J. B. (1970). Predictors of mortality in the adult population of Tecumseh. Archives of Environmental Health, 21, 418-424. 
Krueger, D. E., Rogot, E., Blackwelder, W. C., and Reid, D. D. (1970). The predictive value of a postal questionnaire on cardiorespiratory symptoms. Journal of Chronic Diseases, 23, 411-421.

Lambert, P. M. (1970). Mortality follow-up of a postal survey of cardiorespiratory disease. British Journal of Preventive and Social Medicine, 24, 62.

Lambert, P. M., and Reid, D. D. (1970). Smoking, air pollution and bronchitis in Britain. Lancet, 1, 853-857.

Lee, P. N. (1976). Statistics of smoking in the United Kingdom. Tobacco Research Council, Research Paper No. 1, 7th edition. Tobacco Research Council: London.

Medical Research Council (1966). Questionnaire on respiratory symptoms and instructions for its use. Medical Research Council: London.

Peto, R., and Pike, M. C. (1973). Conservatism of the approximation $\Sigma(0-E)^{2} / E$ in the logrank test for survival data or tumour incidence data. Biometrics, 29, 579-584.

Reid, D. D. (1966). Studies of disease among migrants and native populations in Great Britain, Norway and the United States. I Background and design. National Cancer Institute. Monograph No. 19, pp. 287-299. National Cancer Institute: Bethesda.

Reid, D. D., Cornfield, J., Markush, R. E., Seigel, D., Pedersen, E., and Haenszel, W. (1966). Studies of disease among migrants and native populations in Great Britain, Norway and the United States. III Prevalence of cardiorespiratory symptoms among migrants and native born in the United States. National Cancer Institute. Monograph No. 19, pp. 321-346. National Cancer Institute: Bethesda.

Rose, G. A. (1968). Variability of angina: some implications for epidemiology. British Journal of Preventive and Social Medicine, 22, 12-15.

Rose, G. A. (1971). Predicting coronary heart disease from minor symptoms and electrocardiographic findings. British Journal of Preventive and Social Medicine, 25, 94-96.

Rose, G. A., and Blackburn, H. (1968). Cardiovascular Survey Methods. WHO: Geneva.

Rose, G. A., McCartney, P., and Reid, D. D. (1977). Self-administration of a questionnaire on chest pain and intermittent claudication. British Journal of Preventive and Social Medicine, 31, 42-48.

World Health Organisation (1957). International Classifcation of Diseases, 7th revision. WHO: Geneva.

Young, J. L. (1974). Cardiorespiratory symptom prevalence among Norwegian migrants to the United States and siblings still alive in Norway with an adjustment for sibship size. Institute of Statistics Mimeo Series No. 922. Institute of Statistics: University of North Carolina, USA. 